\title{
WHY ARE CASUAL EMPLOYMENT AND CASUALISATION \\ LESS SIGNIFICANT IN NEW ZEALAND THAN IN AUSTRALIA?
}

\author{
Iain Campbell \\ Department of Industrial Relations, Griffith Business School, \\ Griffith University, Brisbane, Australia \\ Peter Brosnan \\ Griffith University \\ Brisbane, Australia
}

\begin{abstract}
New Zealand and Australia seem to share a common experience of casual work. In both countries a category of 'casual' has long been permitted under labour regulation, and in both countries this has led in practice to both 'irregular' and 'regular' casuals. At least up until the recent period, labour regulation in both countries sought to limit casual employment in similar ways through quantitative restrictions and through prescription of a 'casual loading' on the hourly rate of pay. Yet, in spite of these strong parallels, casual employment is less significant in New Zealand as a proportion of the total workforce and it has failed to show the same pace of growth as in Australia. This paper asks why there should be this difference. It sketches out an answer that focuses on employer calculations and choices (within the framework of labour regulation, including custom and practice). We suggest that the relative advantages of casual employment to employers are narrower and less imposing in New Zealand. This is partly because of compression at the bottom, as a result of the fact that all employees can claim access to basic rights and benefits under a statutory 'minimum code'. But also crucial is compression from the top. Permanent workers in New Zealand have fewer benefits than permanent workers in Australia, but their situation was markedly worsened as a result of the radical program of labour market deregulation in the 1990s. As a result of this narrowing of the shortfall in rights and benefits, employers have less incentive to replace permanent workers with casual workers.
\end{abstract}

\section{Introduction}

The paper explores a comparison between Australia and New Zealand. We start with the familiar Australian phenomenon of casualisation and the underlying category of 'casual' work. We work our way outward from this starting-point, examining what is known about analogous processes of labour restructuring in New Zealand. This analysis promises to throw light on the distinctive features of the Australian experience. At the same time, as the title indicates, we are using the presumptions of the Australian literature in order to pose questions about New Zealand. In this way, we hope to open up new lines of analysis and develop new knowledge about the New Zealand experience.

The first section looks at two features of casual work in Australia: the relation to labour regulation and data on the size and rate of growth of casual work. The second section looks at what is known about casual work in New Zealand. There are several strong similarities, primarily at the level of labour regulation, which render New Zealand closer to Australia than almost any other OECD country. In New Zealand, as in Australia, a category of 'casual' has traditionally been permitted under labour regulation, with similar efforts to develop quantitative restrictions and payment of a casual loading. Yet, even at this level, it is possible to spot subtle differences.
Moreover, there is a strong difference as a result of the fact that casual work, though significant, is much less common in New Zealand than in Australia, and it does not appear to be growing across the economy as a whole.

The third section considers the crunch question: Why are casual employment and casualisation less significant in New Zealand than in Australia? It draws on the conceptual framework used in explaining casualisation in Australia. The emphasis here is on employer calculations and choices (within the framework of labour regulation, including custom and practice). Our proposed answer places casual work in a broader context of labour restructuring. The key aspect here concerns the relative advantage of casual work to employers in comparison with alternatives such as permanent work. We suggest that the relative advantages of casual employment to employers are narrower and less imposing in New Zealand.

\section{Casual Work and Casualisation in Australia}

Casual work and casualisation in Australia have attracted a great deal of research over the past fifteen years in Australia. At latest count, around eighty scholarly articles, reports or books have taken up aspects of the topic. There is no room here to summarise all that is 
known (for recent contributions see Pocock, Buchanan and Campbell, 2004; O'Donnell, 2004). We just summarise two points that seem particularly salient.

\section{Casual Work and Labour Regulation}

Casual employment was an old form of employment, prominent in Australia in industries such as the waterfront, construction, shearing, meat preserving and flour milling (O'Donnell, 2004, 12). It was marked by a strong degree of commodification, where the worker enjoyed little more than a simple entitlement to a money wage in exchange for labour performed.

As labour regulation has developed, casual employment has come to be firmly embedded in labour regulation. Indeed, it is impossible to understand casual employment without an appreciation of the structure of labour regulation.

The Australian system has had little statutory regulation. The main vehicle of labour regulation has been through the arbitration system and the awards produced by itlegally binding prescriptions of wages and conditions laid down by independent quasi-judicial tribunals (Creighton and Stewart, 2000). Though a complex patchwork, the award system, together with supplementary agreements, acted reasonably effectively to generalize minimum conditions to a majority of the waged workforce. Coverage was broad. Though declining during the $1970 \mathrm{~s}$ and 1980s, it was still 80 percent of all employees in 1990 (Campbell and Brosnan, 1999). On the other hand, however, enforcement was often poor, leading to an undermining of award regulations in sectors where noncompliance became widespread.

in most awards, full-time permanent employment was the axis along which standard rights and benefits were defined. Other forms of employment were covered in special clauses, which often specified exemptions from the standard provisions. The vast majority of awards included a casual clause, which allowed some employees to be hired without standard rights and benefits (but with a casual loading on the hourly rate of pay).

The substantive content of casual clauses can be easily summarised. First, the definition of casual was generally very broad, with employees often defined in awards and agreements, somewhat tautologically, as 'casual' because they are paid 'as such'. Second, casual clauses generally offered some mechanism of control, designed to limit the use of casual employment. However, these controls were generally poorly designed. Sometimes they set restrictions on how casuals could be used, such as when, under what conditions and for how long, but more often they trok the simple form of proportional limits or quotas (casual employees calculated as a proportion of the total number of employees or total number of hours). The third point relates to the extent of the exemptions fiom rights and henefits. The precise extent varied from award to award, but in general it was surprisingly wide. Casual employees had relatively few rights and benefits in awards and agreements, apart from the right to an hour's wage in exchange for an hour of work performed. Finally, we can note that a casual loading on the hourly rate of pay was found in almost all awards (justified as compensation for foregone benefits, as compensation for irregular employment and as a deterrent for employers).

The history of award regulation of casuals stretches back to the origins of the arbitration system. It is likely that award regulation in areas where casual workers existed initially aimed just to boost wages through a casual loading on a base rate of pay. In making the Builders Labourer's Award in 1913, Justice Higgins noted the point that casual pay for builders' labourers - a group who were employed casually at the time - should be higher to compensate them for the uncertainty of their employment. In making the award, Higgins noted that that "not one employer objected" (Builders Labourer's 7 Com Arb 210,218 (1913)).

This structure of award regulation persisted through to the end of the century in Australia, though with some amendments (including supplementing awards with independent agreements in the changes since the early 1990s). An audit of 50 federal awards conducted in 2000 (Commonwealth Government, 2000, 32-37, see also Attachment B, Schedule A), suggested that almost all (47) had casual clauses. All of these incorporated loose definitions of casuals. All but two of these provided for a casual loading, most commonly twenty percent. The audit took place after the Workplace Relations Act 1996 proscribed quotas, and it indicated that, while twelve had restrictions on the length of engagement of casuals, most had no restrictions or much looser restrictions.

Given the relative lack of statutory regulation and the vagaries of regulation through the common law, award regulation has been crucial in shaping the practice of casual employment. The overall effect was to establish a divide in the employment structure (and the workforce). Not only was casual work the most common alternative form of employment, but it also displayed the largest reduction or shortfall of rights and benefits. The shortfall permitted for casuals spanned numerous dimensions of the employment relation, extending well beyond the employment insecurity often associated with casual work.

Casual clauses can be viewed as a type of 'officially sanctioned' gap in the regulatory system. As a result, casual work is regulated but it is not protected. However, this is not the only gap in labour regulation. The Australian system is highly porous and opaque, and the effectively-regulated sector is surprisingly small. Two other gaps, associated with the poor coverage and the poor enforcement of existing rules, also provide fertile soil within which unprotected employment can survive and flourish (Campbell, 1996). Thus, casual employment can be seen as a form of employment that straddles the border between the regulated and unregulated sectors, displaying a shortfall in protection in both sectors.

The features of labour regulation identified above help to define the opportunities for employers. Numerous casual clauses, broad definitions, poor controls, together with 
poor coverage and poor enforcement, mean that labour regulation provides few barriers to the use of casual employment. In short, in the absence of other barriers, casual work appears readily available to employers. At the same time, the fact that casual employment - even in the effectively-regulated sector - displays such a large shortfall in protection means that casual work appears as a highly flexible resource, which offers employers numerous advantages and can be used by them in many different ways.

Given these features, it is not surprising that casual jobs can be highly diverse. For example, around two thirds of workers classified as 'casual' in their main job are parttime (representing approximately 60 percent of all parttime waged workers), while the remaining one third are full-time (representing approximately 13 percent of all full-time waged workers). Diversity in casual jobs is matched by diversity both in the groups that participate in casual work and in the forms of their participation. One crucial aspect concerns the peculiar phenomenon of what are sometimes called 'regular' (or 'long-term' or 'permanent' or 'ongoing') casuals, often distinguished from 'irregular' ('short-term' or 'true') casuals. Such workers are used by employers in a regular, long-term manner that is similar to the manner in which permanent employees are used. However, they are deprived of the standard rights and benefits normally associated with permanent work. In effect employers are able to abuse the opportunities of casual status, by substituting such casual workers for permanent workers.

It is difficult to estimate the precise extent and pattern of growth of regular casuals. One calculation can be derived from a 1995 survey of workplaces conducted in Australia (Brosnan and Walsh, 1996, 1998). It generated an estimate for 'occasional' workers of 9.9 percent. A rough comparison with the 1995 ABS figure for 'casual' employees (23.7 percent), which includes both irregular and regular casual workers, suggests that regular casuals could be around 13.8 percent of the workforce. Another familiar measure One familiar measure is in terms of accumulated tenure. This is not at all satisfactory, but it does provide an insight into one dimension of the issue. Recent HILDA data (Table 1) indicate that casual workers tend to have substantially shorter accumulated tenure than both permanent workers and fixed-term workers. Nevertheless, most casual workers have been in their job for longer than one year (and, presumably, some of those with accumulated tenure of less than one year will also last for a long period in their jobs before they finally leave).

In short, the category of casual in Australia covers distinct ways of using casual workers. There is a large amount of irregular and short-term casual work. But perhaps most surprising (and most problematic) is the large amount of regular casual employment, in which employees are able to build up long periods of tenure.

Table 1: Current Job Tenure, Selected Types of Employee a), Australia, 2001 (\%)

\begin{tabular}{|l|c|c|c|c|}
\hline & $\mathrm{P}$ & $\mathrm{F}$ & $\mathrm{C}$ & All employees \\
\hline Under 1 year & 15.4 & 31.3 & 43.1 & 23.8 \\
\hline 1 and under 5 years & 36.4 & 40.8 & 41.5 & 38.0 \\
\hline 5 and under 10 years & 19.6 & 14.8 & 8.5 & 16.4 \\
\hline 10 years or more & 28.7 & 13.2 & 6.8 & 21.8 \\
\hline & & & & \\
\hline Mean years of job tenure & 7.3 & 4.4 & 2.6 & 5.8 \\
\hline
\end{tabular}

a) excluding owner-managers of incorporated enterprises

Key: $\mathrm{P}$ - permanent/ ongoing; $\mathrm{F}$ - fixed-term contract; $\mathrm{C}$ - casual.

Source: HILDA Survey Wave 1, weighted data from Wooden and Warren, 2003, 13, some percentages have been summed in order to fit aggregate categories.

\section{The Size and Rate of Growth of Casual Work}

The official statistics confirm the large size of the casual workforce. According to one conventional measure used by the Australian Bureau of Statistics (ABS), a 'casual employee' can be defined as an employee who is not entitled (in his or her main job) to paid annual leave and paid sick leave. This is a robust definition, which captures important aspects of the practice of casual employment (Campbell and Burgess, 2001). 'Casual employees' in this sense numbered 2,239,900 persons in August 2003.
They represented 27.6 percent of all employees (or around 23.6 percent of the total employed labour force). These figures point to a trajectory of strong growth or casualisation, the number having risen from 850,000 persons or 15.8 percent of all employees in 1984 (see Figure 1). The rate of growth was most powerful in the 1980 s and early 1990s, but it has slowed down in the period of employment growth since the mid-1990s, just keeping ahead of the expansion in other forms of employment. 


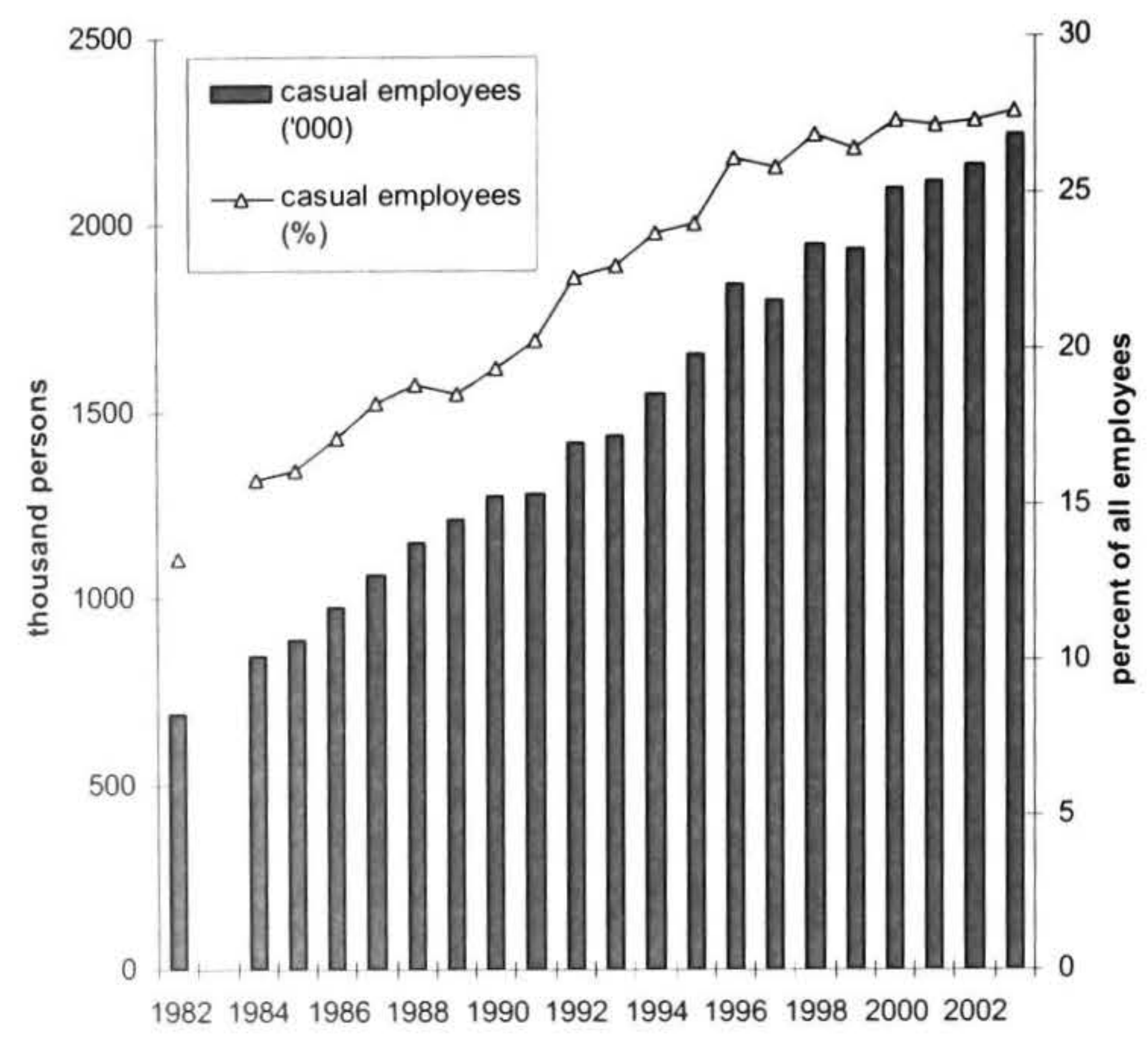

Source: 1982 - ABS, Alternative Working Arrangements, March to Mav 1982, Cat. No. 6341.0; 1984-1987 - estimates calculated from ABS, Employment Benefits Australia, Cat. No. 6334.0; 1988 and 1990 - from unpublished data derived from ABS, Weekly Earnings of Employees (Distritution), Australia, Cat. No. 6310.0 (Romeyn, 1992); 1989, 1991-1995, 1997 - ABS, Weekly Earnings of Employees (Distribution), Australia, Cat. No. 6310.0 and Product No. 6310.0.40.001; 1996 - ABS, Trade Union Memhers, Australia. August 1996, Cat. No. 6325.0; 1998-2003 - ABS, Employee Earnings, Benefits and Trade Union Membership. Australia, Cat. No. 6310.0.

\section{Casual Work in New Zealand}

Unfortunately, research into casual work in New Zealand is relatively meagre. Moreover, labour force data are less detailed than their Australian equivalents. Nevertheless, it is possible to develop a few tentative arguments.

New Zealand exhibits some strong similarities to Australia in its experiences of casual work. The most compelling parallel is at the level of labour regulation. Statutory regulation of labour conditions has been more important in New Zealand than in Australia. Nevertheless, beginning from the end of the $19^{\text {th }}$ century, New Zealand developed a similar - though by no means identical - labour regulation system, which supplemented statute with compulsory conciliation and arbitration and the setting down of awards (Macintyre, 1987). As in Australia, the award system functioned as the main mechanism of generalization to spread gains in wages and conditions to the vast majority of workers. However, as Schwartz (2000, 78-79; see also Barry and Wailes, 2004) points out, the New Zealand version was more weakly institutionalised and had less comprehensive coverage, even during its heyday. Even prior to the abolition of the award system in 1991, many workers in strong unions stood outside the award system and relied on so-called 'enterprise bargains' to improve wages and conditions. Coverage was estimated as just 60 percent in 1987. As in Australia, poor enforcement was also a problem, exacerbated by the large number of small employers in the New Zealand economy.

\section{Casual Work and Labour Regulation}

As in Australia, the use of casual labour in New Zealand pre-dates the arbitration system (e.g. Martin 1990). As labour regulation developed, casual labour was integrated into the system. New Zealand's Court of Arbitration would seem to have led the way. Explicit casual loadings had been in New Zealand's awards for about a decade before Higgins' 1913 decision in Australia.

The substantive content of awards in Australia and New Zealand developed to have similarities (and some subtle differences). New Zealand awards, like those in Australia, defined rights and benefits for permanent employees but allowed room for other forms of employment through special clauses. Casual clauses were common, but they were not in all awards (New Zealand Treasury, 1990, 148). The definitions of 'casual' varied from award to award, but they tended to be tighter and more specific than in Australia. In particular, the definitions often explicitly incorporated a notion of restriction in the use of casual workers. They tended to stress that the engagements of casuals should be on an "as needs" basis, and they often imposed limits on the engagement of casuals; the maximum duration of employment - usually about a week, and a minimum 
period of payment (and hence of work) - usually about three hours a day. When the definition was restrictive, there was little need for a separate mechanism of control. It is difficult to gauge the precise extent of the exemptions from standard rights and benefits that were associated with casual work. However, the general principle of casual wage as work with only a basic entitlement to an hourly wage seems to have been influential. In common with Australia, the clauses often stipulated a casual loading on the hourly rate of pay. In common with Australia, these loadings sometimes were designed to penalise employers for using casual labour, and sometimes to compensate the worker for lost earnings due to the casual nature of the work. Once the awards constrained the use of casuals, the first intention became the main one. In some awards the casual loading was non-existent; in others it was at least as high as one-third (e.g. Wellington District Grocers' Assistants Award, 1931).

In spite of some differences, the two systems developed in parallel, often copying each other's innovations (Woods, 1963). However, New Zealand has been able to use statute to supplement award regulation to a much greater extent than Australia. After World War II, New Zealand introduced legislation which provided some basic rights for all workers, such as the Holidays Act 1946 and the Minimum Wage Act 1946. These gave some protection to casual workers who may not have been covered adequately by an award. Nonetheless, the loose nature of casual employment probably allowed some employers to evade their responsibilities and, as in Australia, gaps and a lack of enforcement left casual employment at the margins of the labour market such that New Zealand casual workers in New Zealand, along with those in Australia, straddle the border between the regulated and unregulated sectors.

There seems less evidence of diversity in the characteristics of casual work in New Zealand than in Australia. However, the paradoxical presence of 'regular' casuals can also be detected. Whatman, Harvey and Hill $(1999,5)$ state that they "encountered definitions of casual workers as casual-casual, regular-casual and permanent casual" in the three industries of accommodation, winemaking and brewing. The term is mentioned in some awards (Ferguson, 1997), though it is difficult to assess their significance.

Awards were abolished as a result of the Employment Contracts Act in 1991, to be replaced by a system that preserved some room for single- and multi-employer collective agreements but was primarily oriented to individual contracting. Casual employment fitted beautifully into the Employment Contracts Act environment (Ferguson, 1997). The Employment Relations Act, which the incoming Labour government introduced in 2000, reversed in part the earlier Act, but it failed to restore awards.

The disappearance of awards did not mean the disappearance of the label "casual", which continued to be used as a term in everyday parlance, to be mentioned in written contracts, and to appear in provisions in statute and common law judgments. Nevertheless, it did seem to have an effect on the regulation of casuals. The collective agreements that succeeded awards sometimes just rolled over the provisions of the award. However, in the medium term, casual clauses tended to be dropped from agreements and where they survived they often failed to specify a casual loading.

New Zealand law does seem clearer as to what is casual labour, although it is still a "grey area" (Ferguson,1997, p.123). In general, the courts have found that to be a casual employee, work must be irregular and uncertain. Even where an employee is explicitly employed as a casual, such as a written contract which specifies as such, if the pattern of work becomes regular the worker will have become a part-time or full-time permanent employee. Thus, to cease to offer work once such a pattern of employment had become established would constitute a dismissal, and the former employee could seek a legal remedy (Butterworths ER 103.20). This is not to say that a person could not be a permanent casual. For example, a catering firm whose contracts are themselves irregular might have a group of waiters on their books that are offered work for each function catered for. Thus the relationship might continue for many years, but work each week would be uncertain and irregular depending on the contracts won (Butterworths ER103.20).

In short, there are strong parallels in the relationship between labour regulation and casual work between New Zealand and Australia. However, there are also some subtle differences. One important difference is the provision of rights and benefits for casual workers through statutory provision. Moreover, even with respect to award regulation before 1991, New Zealand differed from Australia as a result of the tighter restrictions on casual work, which seemed more likely to be based on limits on the length of engagement of casuals. This tended to restrict casual work in practice to short-term and irregular work. Finally we can note that the abolition of awards seems to have been accompanied by a disappearance of casual clauses and provisions such as the casual loading.

\section{The Size and Rate of Growth of Casual Work}

Where New Zealand most obviously differs from Australia is in relation to estimates of the size and pace of growth of casual employment. Data on the size and nature of the casual workforce are sparse, and there is little case-study research to fill the gaps in knowledge (but see Whatman, Harvey and Hill, 1999; WEB Research, 2004). Two Department of Labour phone surveys of employees in 1993 and 1997, which divided employees into only 'permanent' and 'casual', produced estimates for casual employment of 11 percent (Tucker, 2002, 21). One of the few other data sources is a workplace survey (Brosnan and Walsh, 1996, 1998; Allan et al, 2001), conducted in 1995 in New Zealand (and simultaneously in Australia and South Africa). This produced an estimate for 'occasional' employees, defined as "employees hired on a periodic basis as need arises", 
of 5.4 percent of the New Zealand workforce. The term occasional was used for two reasons: because the term casual is not widely known in South Africa, and also to capture the genuinely casual in the Australian data. This category is sometimes identified in the published results as 'casual' or 'casual/ occasional' (Brosnan and Walsh, 1998, 29-30), and it is a different measure than the Australian Bureau of Statistics measure of casual. If we bring together the categories of 'occasional', 'temporary' and 'fixed-term' from that study, the proportion is recorded as 11 percent (Brosnan and Walsh, 1998, 2931). which is identical to the Department of Labour figure.

Though the precise extent is unclear, these figures suggest that casual workers represent a sizeable proportion of the workforce in New Zealand. However, this is still much less than the comparable figure for Australia. Any Australia-New Zealand comparison is complicated by the different categories in the available data. However, the 1995 workplace survey does allow a direct comparison using similar categories. The category of 'occasional' was 9.9 percent in Australia (compared to 5.4 percent in New Zealand). If we group together the categories of occasional, temporary and fixed-term, the figure is 14.6 percent in Australia (compared to 11 percent in New Zealand). In commenting on these figures, Brosnan and Walsh (1998, 31) stress that "no matter which definition we use, be it casuals, casuals plus temporaries, casuals plus temporary plus contractors/ consultants and so on, Australia has less of its labour force in secure employment than New Zealand".

II seems clear that New Zealand has fewer casual workers in its employment structure. It clearly has fewer genuine or irregular casuals. It is unlikely to have anywhere near the same number of regular casuals. It still may be true, however, that some industries have significant numbers of casuals. For example, case studies of industries such as accommodation, call centres and labour hire in construction point to a predominance of casual and temporary work (Whatman, Harvey and Hill, 1999; WEB Research, 2004; see Hannif and Lamm, in this volume).

What about the pace of growth? Casualisation is used as a loose term to cover general trends prior to 1991 (Anderson, Brosnan and Walsh, 1994) or specific trends in industries such as retail (Brosnan, 1991). More recently, casualisation is cited as a trend in industries such as the waterfront (Reveley, 1999) and accommodation (Whatman, Harvey and Hill, 1999, 5, 109). However, it does not seem to be anywhere near as prominent in other industries as in Australia. Evidence from two workplace surveys in 1991 and 1995 in fact suggested a decline in the proportion of 'occasional' workers in the workforee (Brosnan and Walsh, 1996, 910; but c.f. Tucker, 2002, 31). As Carroll (1999, 120) notes, the evidence is thin. However, it is certainly not suggestive of the strong growth apparent in Australia.

\section{Why Are Casual Employment and Casualisation Less Significant in New Zealand?}

So, why are casual employment and casualisation less significant in New Zealand? Is the lesser number of casual workers a positive indicator, which reflects well on the policies followed in the 1980s and 1990s? Does it mean that there is less precariousness in the New Zealand labour market?

Drawing on the analysis developed for Australia, we can frame the answer to these questions in terms of the interactions between employer calculations and choices and the labour regulation system.

Casualisation in Australia cannot be explained by appealing to structural change or shifts in employee choices. Most researchers, including ourselves (Campbell and Brosnan, 1999), emphasise the so-called demand side of the labour market, encompassing the impact of labour regulation and employer calculation and choices. Our analysis suggests that the crucial mechanism for changes in the significance of casual employment is employer choices about the structure of employment in their enterprise, primarily based on perceptions of the relative advantages of casual employment (Campbell, 2001). A crucial shift took place in the 1970s, linked to increased competitive pressures and weakened labour market conditions. As a result employers started to show an increasing willingness and an increasing ability to realise the advantages of casual work.

It should be noted that the explanation does not rely on changes in labour regulation. We stress an underlying continuity in the relevant features of labour regulation. The patchwork nature of the system, marked by numerous hidden gaps, and without any underpinning floor of basic rights, was decisive in making casual employment available to employers. However, the system had been little changed in the way it treated casual work since the early years of the twentieth century. It is true that the labour regulation system has changed in other ways, in particular as a result of the neo-liberal program of "labour market deregulation' in the 1990s. This can be seen to have had a slight direct impact. On the one hand, 'deregulation' has opened up more opportunities for the use of casuals - loosening award restrictions, enhancing employer power and contributing to changes in employer perceptions. It has widened the existing gaps (Campbell and Brosnan, 1999, 360-362, 371-374). However, 'deregulation' was mainly aimed at the wages and conditions of permanent workers. So far it has had only a slight direct impact in this area, though there has been some signs of deterioration in wages and conditions for part-time permanent workers (Campbell and Brosnan,
1999). 
From the mid-1970s on, New Zealand employers faced just as much economic pressure as their Australian counterparts. Perhaps more. They could use the category of 'casual' if they wanted. But they did not (or at least not to the extent that employers did in Australia). Why not?

We put to one side the vexed issue of theorising employer interests in detail and instead rely on a model of simple profit maximisation. We concentrate on examining the relative advantages of using casual employment, first in Australia and then in New Zealand. Australian employers gain five types of advantage by using casual labour. First, they gain operational, financial and administrative flexibility. Secondly, they can dismiss a casual worker without fear of legal or financial claims. Thirdly, they save on various benefits which permanent and fixed-term workers gain by right (although these are offset by the casual loading). Fourthly casuals are rarely eligible for promotions or to be on experience-related pay scales; thus despite casual loadings, they tend to be the most lowlypaid workers. Finally, the conferring of casual status on a worker gives the employer a psychological advantage. When a worker is told that they are a casual, they are more likely to perceive themselves as being at the periphery of the firm with limited rights. Moreover, the peripheral status of their employment may make them less likely to question managerial decisions on a wide range of issues.

The first and fourth sets of advantages arise out of the very nature of casual labour and apply equally in New Zealand. The second is quite different. As we discussed above, New Zealand law gives better protection to casual workers, and a casual worker whose hours become regular would be deemed to be part-time worker, and would have legal rights should they be dismissed unfairly or due to redundancy (Ferguson, 1997; Butterworths ER 103.20), and there is also the danger that an employer who misuses casuals may find themselves in a difficult position if they are inspected by the Department of Labour. These possibilities do not stop unscrupulous behaviour, for some employers have been found not paying casuals their holiday pay. But they do discourage it.

As to the last advantage, the psychological benefits for the employer, this may apply with equal force in New Zealand. However the greater range of rights may modify its effect in some cases. Nonetheless, the evidence does seem to suggest that some New Zealand employers do use casual employment to keep their labour force more subservient (see the paper by Hannif and Lamm in these proceedings).

The third advantage for Australian employers is more complicated and difficult to evaluate. The most important relative benefits for casuals and permanent or fixed-term workers are set out in Table 2. The main benefit to Australian employers is that they avoid paying for annual holidays. They also avoid paying for sick leave, and bereavement leave in most states. Where casuals work for a decade or more, employers also avoid long service leave (usually 3 months paid leave after between 10 and 15 years service). Depending on the number of hours worked by casuals, they may also avoid paying the Superannuation levy of 9 percent.

Australian wage cases, which review the casual loading, attempt to monetarise the value of the benefits foregone. The debate ranges around issues such as superannuation, and sick leave and other special leaves which may or may not be taken when they are available. Thus union estimates of the benefits foregone can be over 40 percent. The relevant tribunals generally grant loadings of the order of 20-25 percent. While the union estimates are obviously at the high end - assuming the maximum use of sick leave, being paid for all public holidays etc - it is clear that an employer can minimum labour costs by using casual labour. Moreover casual rarely receive pay rises or promotions, thus their basic wage remains low, conferring a further advantage on their employer. To sum up, an employer who uses casual labour carefully can gain considerable financial advantage by paying the casual loading of 20-25 percent and avoiding holiday pay, sick pay, funeral leave, superannuation etc.

The situation in New Zealand is quite different. A cost advantage of casual employment is hard to identify, even given the recent disappearance of casual loadings. New Zealand workers receive fewer benefits, e.g. three weeks annual leave compared with four weeks in Australia, minimal or no long service leave, and no legal guarantee to superannuation. On the other hand, the benefits they do enjoy are available to casuals as well as permanent employees. The new Holidays Act 2003, follows earlier Holidays Acts in specifying eleven public holidays, and three weeks paid annual leave (after 12 months employment). The new act extends employee rights by giving a statutory right to five days special leave (after six months employment) for all employees. Thus there is no obvious financial benefit from using casuals, other than they may be employed on the lowest rates of pay.

The changes over the past twenty years in New Zealand have not, at least at the general level, widened the relative advantages of casual employment. On the contrary, any relative advantages appear to have been compressed. This is largely because of movements that have affected permanent workers. New Zealand experienced similar pressures for 'labour market deregulation' as in Australia, but the outcome in New Zealand was much more radical and comprehensive. As noted above, this had some effect on casual work. However, the major effect was on permanent workers. The so-called 'minimum code' survived, and this acted as a floor on wages and conditions for both permanent and casual workers. But some of the rights and benefits specified in awards and agreements for permanent workers - in particular penalty rates - largely disappeared (Harbridge and Walsh, 2002). It is likely that this reduced the relative advantages of casual work and further narrowed the shortfall between permanent work and casual work. Using some of the 'flexibility' opened up in connection with permanent workers may have been more attractive than using casuals. This in turn starts to blur the basic divide between permanent and casual work. 
Table 2: Employment Form and Employment Benefits

\begin{tabular}{|c|c|c|c|c|c|c|c|}
\hline & $\begin{array}{c}\text { Paid } \\
\text { holidays }\end{array}$ & $\begin{array}{l}\text { Paid sick } \\
\text { leave }\end{array}$ & $\begin{array}{c}\text { Unpaid } \\
\text { maternity } \\
\text { /paternity } \\
\text { leave }\end{array}$ & $\begin{array}{c}\text { Paid } \\
\text { maternity } \\
\text { /paternity } \\
\text { leave }\end{array}$ & $\begin{array}{c}\text { Long } \\
\text { service } \\
\text { leave }\end{array}$ & $\begin{array}{l}\text { Bereavement } \\
\text { leave etc }\end{array}$ & Superannuation \\
\hline \multicolumn{8}{|l|}{ Australia } \\
\hline $\begin{array}{l}\text { Permanent or fixed } \\
\text { term full-time }\end{array}$ & Yes & Yes & Yes & No & Yes & Yes & Yes \\
\hline $\begin{array}{l}\text { Permanent or fixed } \\
\text { term part-time }\end{array}$ & Yes & Yes & Yes & No & Yes & Yes & If $>\$ 450$ a month \\
\hline Casual & No & $\mathrm{W}, \mathrm{V}$ & $\mathrm{Q}, \mathrm{V}, \mathrm{W}$ & No & Q & w & If $>\$ 450$ a month \\
\hline \multicolumn{8}{|l|}{ New Zealand } \\
\hline $\begin{array}{l}\text { Permanent or fixed } \\
\text { term full-time }\end{array}$ & Yes & Yes & Yes & Yes & No & Yes & No \\
\hline $\begin{array}{l}\text { Permanent or fixed } \\
\text { term part-time }\end{array}$ & Yes & Yes & Yes & Yes & No & Yes & No \\
\hline Casual & Yes & Yes & Yes & Yes & No & Yes & No \\
\hline
\end{tabular}

Notes: $Q$ in Queensland.

$\mathrm{V}$ in Victoria.

$\mathrm{W}$ in Western Australia.

\section{References}

Allan, C., Brosnan, P., Horwitz, F. and Walsh, P. (2001) 'Casualisation and Outsourcing: A Comparative Study', New Zealand Journal of Industrial Relations 26 (3), 253-272.

Anderson, G., Brosnan, P. and Walsh, P. (1994) 'Flexibility, Casualization and Externalization in the New Zealand Workforce', Journal of Industrial Relations, 36, 4, 491-518.

Barry, M. and Wailes, N. (2004) 'Contrasting Systems? 100 Years of Arbitration in Australia and New Zealand', Journal of Industrial Relations, 46, 4 . $430-447$.

Brosnan, P. (1991) 'Labour market flexibility and the quality of work: a case study of the retail industry', New Zealand Journal of Industrial Relations 16, 13-36.

Brosnan, P. and Walsh, P. (1996) "Non-Standard Employment in Australia and New Zealand: Results from a Workplace Survey', in J. Teicher ed., Non-Standard Employment in Australia and New Zealand, NKCIR Monograph no. 9, Monash University, 1-22.

Brosnan, P. and Walsh, P. (1998) 'Employment Security in Australia and New Zealand', Labour and Industro 8 (3), 23-41.
Butterworths (n.d.) Butterworths Employment Law Bulletin : Recent Developments in Employment Law. Wellington, Butterworths of New Zealand

Campbell, I. (1996) 'Casual Employment, Labour Regulation and Australian Trade Unions', Journal of Industrial Relations 38(4), 571-599.

Campbell, I. (2001) 'Casual Employees and the Training Deficit: Exploring Employer Calculations and Choices', International Journal of Employment Studies, 9 (1), 61-101.

Campbell, I. and Brosnan, P. (1999) 'Labour Market Deregulation in Australia: the slow combustion approach to workplace change', International Review of Applied Economics, 13, 3, 353-394.

Campbell, I. and Burgess, J. (2001) 'A New Estimate of Casual Employment?', Australian Bulletin of Labour 27 (2), 85-108.

Carroll, N. (1999) 'Non-Standard employment: a note on levels, trends, and some implications', Labour Market Bulletin 1999, 101-121.

Commonwealth Government (2000) Outline of Submissions, The Metal Engineering and Associated Industries Award 1998, Casual Employment, Canberra, Department of Employment, Workplace Relations and Small Business. 
Creighton, B. and Stewart, A. (2000) Labour Law: An Introduction, 3rd ed., Sydney, The Federation Press.

Ferguson, J. (1997) 'Casual Employment Contracts: Continuing Confusion when Protection and Free Market Clash', New Zealand Journal of Industrial Relations 22 (1), 123-142.

Harbridge, R. and Walsh, P. (2002) 'Globalisation and labour market deregulation in Australia and New Zealand: Different approaches, similar outcomes', Employee Relations 24 (4), 423-436.

Macintyre, S. (1987) 'Holt and the Establishment of Arbitration: An Australian Perspective', New Zealand Journal of Industrial Relations 12 (3), 151-159.

Martin, J. E. (1990) The Forgotten Worker: The Rural Wage Earner in Nineteenth-Century New Zealand. Wellington, Allen \& Unwin/Trade Union History Project.

New Zealand Treasury (1990) Briefing to the Incoming Government. Wellington.

O'Donnell, A. (2004) "'Non-Standard" Workers in Australia: Counts and Controversies', Australian Journal of Labour Law 17, 1-28.

Pocock, B., Buchanan, J. and Campbell, I: (2004) Securing Quality Employment: Policy Options for Casual and Part-time Workers in Australia, Sydney, Chifley Research Centre, www.chifley.org.au

Reith, P. (2000) Casual employment and working hours in Australia, Ministerial Information Paper, Canberra, DEWRSB.
Reveley, J. (1999) 'From "Supplementary Seagulls" to "Cut Price Casuals": Changing Patterns of Casual Employment on the New Zealand Waterfront 1951-1997', Labour and Industry 10 (1), 35-56.

Romeyn, J. (1992) Flexible Working Time: Part-Time and Casual Employment, Industrial Relations Research Monograph no. 1, Canberra, Department of Industrial Relations.

Schwartz, H. (2000) 'Internationalization and Two Liberal Welfare States Australia and New Zealand', in F. Scharpf and V. Schmidt eds., Welfare and Work in the Open Economy, vol. II. Diverse Responses to Common Challenges, Oxford, Oxford University Press, 69-130.

Tucker, D. (2002) 'Precarious' Non-Standard Employment - A Review of the Literature, Labour Market Policy Group, Department of Labour, Wellington.

WEB Research (2004) Report of Exploratory Case Study Research into Precarious Employment, Department of Labour, Wellington.

Whatman, R., Harvey, O. and Hill, R. (1999) The Effects of Employment Regulation: Case Study Research in the Accommodation, Winemaking and Brewing Industries, Occasional Paper 1999/4, Labour Market Policy Group, Department of Labour, Wellington.

Wooden, M. and Warren, D. (2003) The Characteristics of Casual and Fixed-Term Employment: Evidence from the HILDA Survey, Melbourne Institute Working Paper no. 15/ 03, June.

Woods, N.S. (1963) Industrial conciliation and arbitration in New Zealand, Wellington, Government Printer. 